This is the final peer-reviewed accepted manuscript of

OPPO, DAVIDE; CAPOZZI, ROSSELLA; PICOTTI, VINCENZO; Ponza, Alessio: A genetic model of hydrocarbonderived carbonate chimneys in shelfal fine-grained sediments: The Enza River field, Northern Apennines (Italy). MARINE AND PETROLEUM GEOLOGY, 66. ISSN 0264-8172

DOI: 10.1016/j.marpetgeo.2015.03.002

The final published version is available online at:

http://dx.doi.org/10.1016/j.marpetgeo.2015.03.002

Rights / License: The terms and conditions for the reuse of this version of the manuscript are specified in the publishing policy. For all terms of use and more information see the publisher's website. 


\title{
A genetic model of hydrocarbon-derived carbonate chimneys in shelfal fine-grained sediments: The Enza River field, Northern Apennines (Italy)
}

\author{
Davide Oppo ${ }^{\mathrm{a},{ }^{*}}$, Rossella Capozzi ${ }^{\mathrm{a}}$, Vincenzo Picotti ${ }^{\mathrm{a}}$, Alessio Ponza ${ }^{\mathrm{b}}$ \\ a Department of Biological, Geological and Environmental Sciences, University of Bologna, Bologna, Italy \\ ${ }^{\mathrm{b}}$ Geophi s.r.l., Bologna, Italy
}

\section{A R T I C L E I N F O}

Keywords:

Authigenic carbonates

Biogenic methane

Shelfal pelitic sediments

Northern Apennines

\begin{abstract}
A B S T R A C T
Methane Derived Authigenic Carbonate (MDAC) concretions have been recently exposed in the Pleistocene Argille Azzurre Fm. outcropping along the Enza riverbanks, Northern Apennines foothills, Italy. The relations between the sediment deposition, the coeval tectonic deformation and the MDAC concretions have been investigated to unravel the mechanism of methane migration through the sediments and the processes leading to MDAC occurrence. The biogenic methane responsible for the formation of MDAC chimneys and slabs has been generated in the organic rich Pliocene sediments located in the Po Plain subsurface. The gas migrated up dip towards the Northern Apennines foothills. The MDAC cements are mainly composed of dolomite, whose precipitation requires thousand years and the absence of $\mathrm{SO}_{4}$ in the pore fluids. According with the sedimentation rates of the MDAC hosting Pleistocene succession, the Sulphate Methane Transition Zone migrated upwards faster than time required for dolomite precipitation. Therefore, the connate water migrating together with the methane could have acted as second DIC source, allowing the MDAC formation also in the methane rich zone.
\end{abstract}

\section{Introduction}

Natural fluid emissions occur in a wide range of geologic and geodynamic settings, with new seepage sites being discovered all around the world. Their study has been mainly addressed to the classification of the emission related structures, often represented by mud volcanoes (e.g. Bonini, 2007; Mazzini et al., 2009), to their role in the degassing of deeply buried sediments (e.g. Dimitrov, 2002 and references therein) and to the emission of greenhouse gases in the atmosphere (e.g. Kvenvolden and Rogers, 2005). Several studies have been recently done on the relations between the evolution of local petroleum systems and the development of fluid emissions (e.g. Aslan et al., 2001; Bonini, 2007; Capozzi and Picotti, 2010; Sun et al., 2012; Oppo et al., 2013, 2014). Moreover, attention has been addressed to the microbiological communities associated with the cold seeps (e.g. Heller et al., 2012) and to their role in degrading the occurring hydrocarbons (e.g. Oppo et al.,

\footnotetext{
* Corresponding author.

E-mail address: davide.oppo2@unibo.it (D. Oppo).
}

2013). The role of the microbe consortia that promote the Anaerobic Oxidation of Methane (AOM), together with Sulphate Reduction (SR) (Boetius et al., 2000), has been also studied to understand the formation of the Methane Derived Authigenic Carbonates (MDAC). These latter represent the main by products of the AOM SR process in marine environment (e.g. Reitner et al., 2005 and references therein).

The MDAC occurrence is reported in various present day marine settings, such as passive and active continental margins, as well as in the geological record (e.g. Magalhaes et al., 2012 and references therein). Their morphologies include crusts, mounds, conduits and irregular bodies. Various pipe like and cylindrical concretions are described in the recent literature (e.g. Mazzini et al., 2003; Clari et al., 2004; Conti et al., 2004; Hovland et al., 2005; Nyman et al., 2010), with diameters typically ranging from centimetres to few decimetres. Exceptionally large struc tures are also documented, reaching more than $10 \mathrm{~m}$ in length and $4 \mathrm{~m}$ in diameter (Nyman et al., 2010). The pipe like concretions, defined in this paper as MDAC chimneys, usually develop in pelitic marine sediments. There is a lack of knowledge about the pro cesses leading to the chimneys precipitation in different time and 
geologic setting. The modern MDAC chimneys form within the sediment pile below the seafloor, thus limiting their direct observation. A single example of authigenic carbonate chimneys developing above the seafloor has been documented in the Black Sea, due to the persistent anoxic condition of the bottom water (Michaelis et al., 2002). Therefore, the onshore fossil records could provide new evidences to reconstruct the fluid migration, in space and time, in relation with the sedimentological and stratigraphic setting where they occur. Moreover, a detailed reconstruction of the processes of MDAC formation into the sedimentary pile could be achieved.

The objective of this work is the study of MDAC chimneys and slabs recently exposed in the Pleistocene deposits along the Enza riverbanks in the Northern Apennines foothills, Italy (Fig. 1). The nearby present day activity of mud volcano fields, where hydrocarbons and saline waters are emitted on the surface, allowed defining the local Miocene petroleum system (Oppo et al., 2013). They could provide a first indication to understand the relation between the Enza MDAC field formation and the active petroleum system. Mineralogy and stable isotope analyses of the MDAC and of their hosting sediments (described in detail in Viola et al., in this volume) have been considered to reconstruct the Enza MDAC field evolution. The relations between the MDAC formation, the sediment deposition and the coeval tectonic deformation have been investigated to unravel how the methane diffuses in the pelitic sediments and control the formation of authigenic carbonates.

\section{Materials and methods}

The study of the Enza River chimney field is based on the detailed reconstruction of the local geologic evolution by means of seismic data interpretation and field surveys. The seismic interpretation has been calibrated by field data (e.g. Ponza, 2010; Ponza et al., 2010; Gunderson et al., 2014) and by the stratigraphic log of San Polo d'Enza 1 hydrocarbon exploration well (Fig. 1).

Four chimneys (En4, En5A, En5B and En1e) and one dark grey carbonate concretion ( $\mathrm{Cr} 1)$ have been sampled during a preliminary survey in April 2010. The analysis of their mineralogy and stable isotopes in the carbonate cements has been conducted at the Georg August University of Gottingen, Germany. Further four samples of carbonate concretions, two chimneys (En5 and En10), one slab $(\mathrm{Cr} 2)$ and one concretion $(\mathrm{Cr} 3)$, together with 31 samples of the hosting sediment, have been collected in May 2013 for their mineralogical and geochemical characterization at the University of Bologna. These latter samples are the main subject of the Viola et al. (in this volume). The concretions have been divided in 29 subsamples to be analysed. The samples have been powdered, homogenized in agate mortar and analysed for mineralogy by $\mathrm{X}$ ray diffractometry (XRD) using a Philips PW 1130 (Cu K $\alpha$ radiation Ni filtered). Estimates of the relative minerals abundance were determined using MacDiff software packages and carbonate mineral compositional limits defined according to Goldsmith and Graf (1958) and Lumsden (1979). Major and trace elements have been

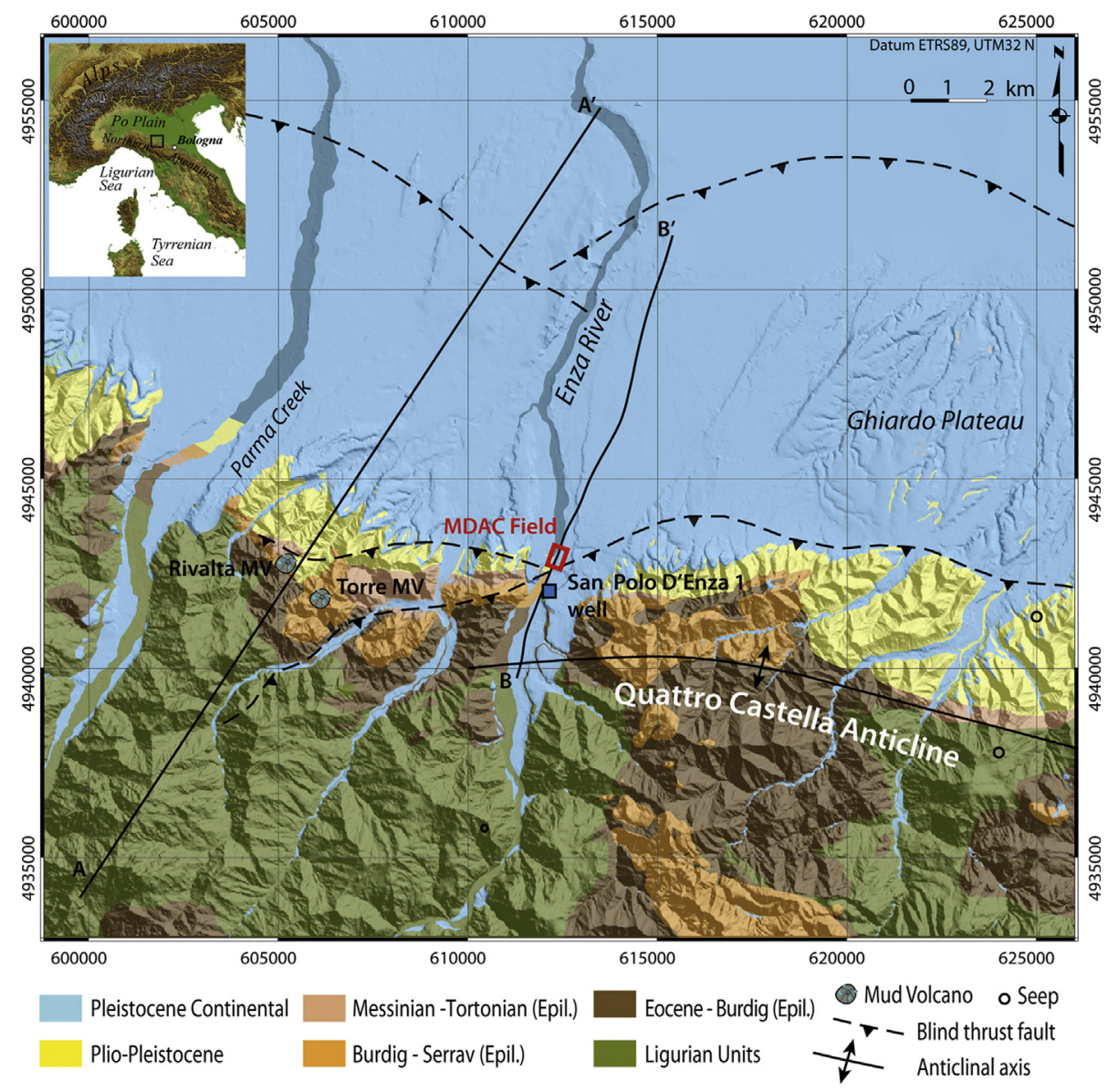

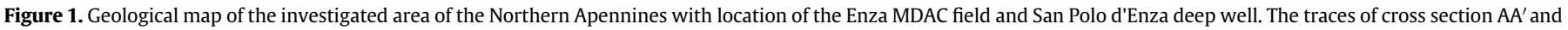
seismic line BB' of Figures 2 and 3 are indicated. The locations of spontaneous fluids seepage are from Oppo et al. (2013). 
determined by $\mathrm{X}$ ray fluorescence (XRF) spectrometry on pressed powered pellets using a Philips PW 1480 automated spectrometer.

The methane gas seeping along the Enza MDAC field has been sampled and analysed to determine its composition and stable isotope abundances at the CNR IGG in Pisa, Italy.

\section{Geological framework}

The Northern Apennines is a fold and thrust belt developing since the Oligocene as a consequence of the collision between Adria and the Corsica-Sardinia block. The Po Basin represents the Northern Apennines foreland basin since the Early Messinian (e.g. Ricci Lucchi, 1986). The studied sector of the Northern Apennines shows the wedge shaped closure of the Ligurian Nappe, which is formed by the Jurassic-Eocene oceanic wedge (Zattin et al., 2002). This nappe thrusted over the Miocene foredeep successions that form the main hydrocarbon reservoirs (e.g. Oppo et al., 2013 and references therein). The folding and thrusting of the Miocene units occurred during and after the Ligurian Nappe emplacement, which acted as seal for the reservoir structures. The activity of recent normal faults, which cut through the seal to the Miocene units, contributed to the formation of numerous spontaneous seepages along the Northern Apennines deformation front (Oppo et al., 2013). The present day mountain range is characterized by rapid Plio Pleistocene uplift and exhumation (Balestrieri et al., 2003; Bartolini, 2003), which led to the transition from exclusively marine to continental environments, as documented by the successions outcropping along the foothills (Ghielmi et al., 2010; Scardia et al., 2012; Gunderson et al., 2014).

The geological setting reconstructed in the cross section $\mathrm{AA}^{\prime}$ of Figure 2, which is located few kilometres to the west of the Enza River (Fig. 1), shows Miocene foredeep units deformed in two different thrust sheets detaching in the Burdigalian units. This deformation is responsible for the up dip migration of hydrocarbons and saline waters towards the thrust tops. The fluids presently leaking through normal faults crosscutting the sealing Ligurian Unit are emitted on the surface by the active mud volcano fields of Rivalta and Torre (Oppo et al., 2013).

\section{Results}

\subsection{Geological setting of Enza River MDAC field}

The Enza MDAC field succession is related to the evolution of the Northern Apennine foothills, shown in the seismic line of Figure 3. The seismic line strikes SSW-NNE along the floodplain of the Enza River, across the mountain front and the Ghiardo plateau, an $\mathrm{E}-\mathrm{W}$ elongated hill located a few kilometres to the north (see trace $\mathrm{BB}^{\prime}$ in Fig. 1). To the South of the Enza MDAC field, the Ligurian Nappe over thrusts the deformed Miocene foredeep units. This structure, named Quattro Castella anticline, is the leading edge of the fault related fold that propagates from a detachment plane within the Ligurian Nappe and locally defines the present day mountain front (Gunderson et al., 2014). The Plio Pleistocene reflectors overlying the Ligurian Nappe show growing geometries (Fig. 3), evidencing the tilting of the Quattro Castella anticline forelimb during this time interval. The Enza chimneys field is located in the outcropping stratigraphic section of this forelimb.

To the North, the geometry of the seismic reflectors documents that the Ghiardo plateau is an actively growing fold, related to blind thrust propagation. In the southern limb of the anticline, the Tor tonian foredeep succession shows parallel reflectors, possibly with an erosional truncation at the top. The activity of the Ghiardo anticline in the Late Tortonian is also marked by the onlap of the Messinian units above the structure. The Pliocene units within the hanging wall syncline and above the structural high show parallel and continuous high amplitude reflectors, documenting a draping phase that rule out further deformation during this time interval. At the top of the Ghiardo anticline, the Pleistocene deposits, on the contrary, progressively thin and onlap the structural high. This fold activity is also documented at outcrop by deformed Middle to Upper Pleistocene continental deposits (Cremaschi and Papani, 1975; Ponza et al., 2010).

\subsection{The stratigraphic section of Enza River MDAC field}

The MDAC slabs and chimneys outcropping along the Enza riverbanks are located in a fine grained succession belonging to

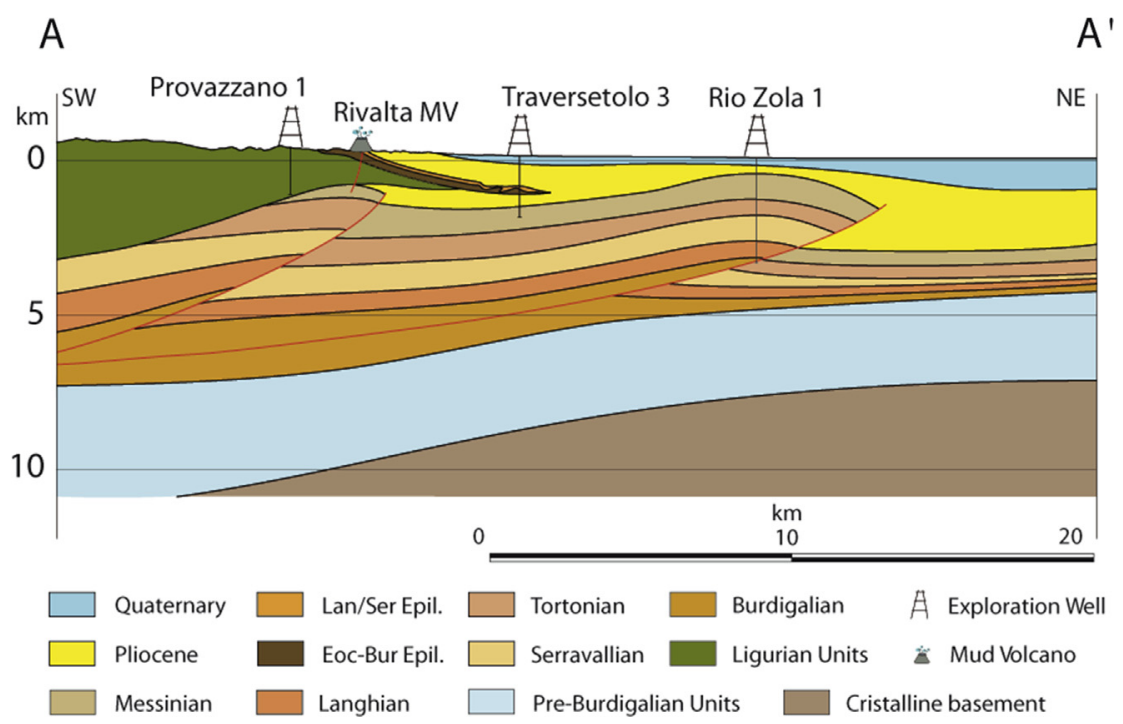

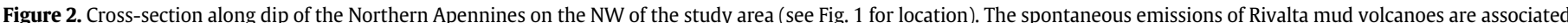

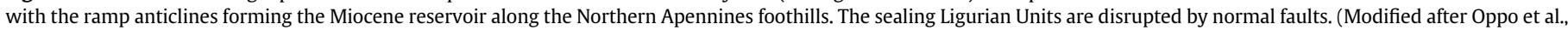
2013). 


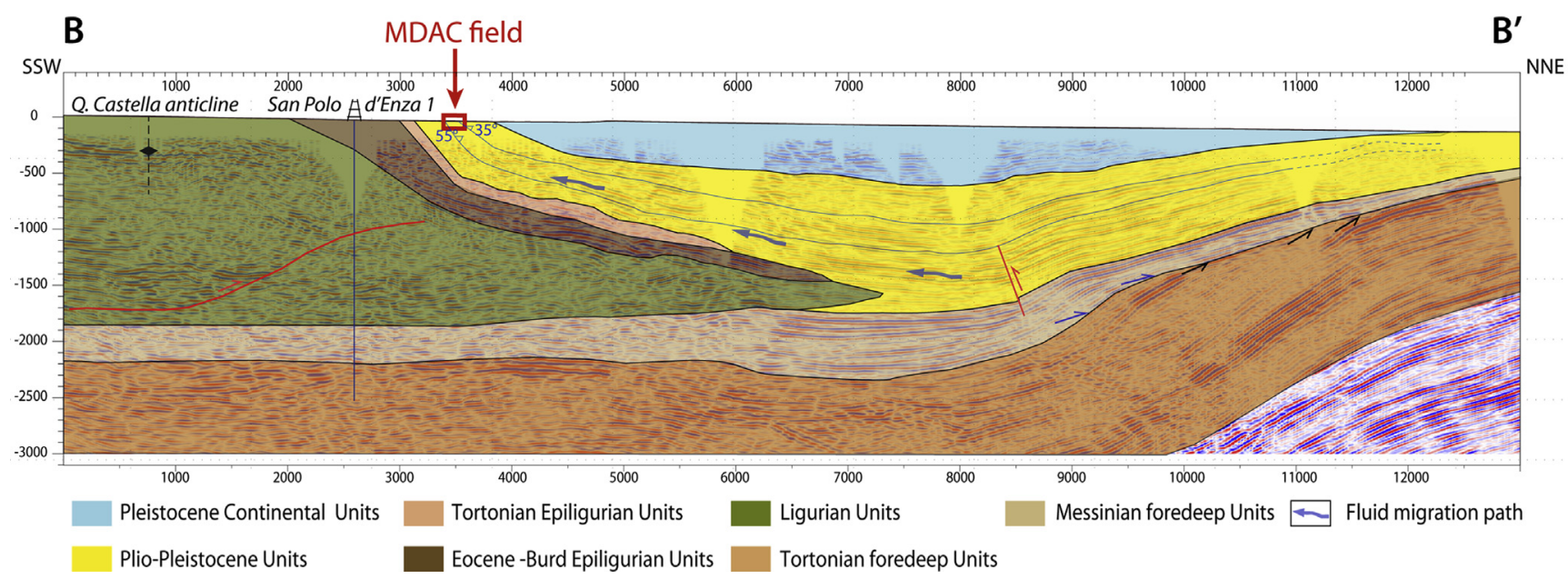

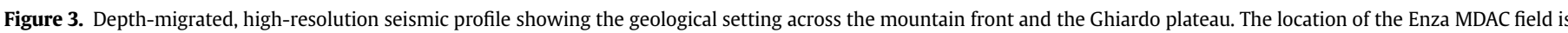
shown. For further explanation see text.

the Lower Pleistocene Argille Azzurre Fm. (Fig. 4). The outcropping section of the Argille Azzurre is formed by ca. $140 \mathrm{~m}$ of inner shelf blue grey silty clays, with intervening sandy layers that are more frequent moving towards the top of the section. This succession represents the last marine interval before the transition to continental deposits (Gunderson et al., 2014). Detailed stratigraphic analyses revealed that the Argille Azzurre Fm., between 0 and $64 \mathrm{~m}$, encompasses the Lower Pleistocene (ca. 1.65 to 1.4 $\mathrm{Ma})$ and has been deposited at an average sedimentation rate of $0.28 \mathrm{~m} / \mathrm{ky}$ (Gunderson et al., 2014; A. Negri, personal communication).

In the MDAC field section, the bedding planes of Pleistocene marine deposits, striking NW-SE, show dips ranging from $55^{\circ}$ to $42^{\circ}$ moving upsection (Fig. 4), indicating a mean deformation rate of $0.05^{\circ} / \mathrm{ky}$. At the top of this interval a $2 \mathrm{~m}$ thick calcarenite horizon marks a major depositional change. In this horizon, a corallinaceous assemblage has colonized dark micritic carbonate concretions, chimneys fragments and reworked coarse siliciclastics (Fig. 5). The calcarenite horizon dips $35^{\circ}$, defining a significant angular unconformity. Considering conservative deformation and a sedimentation rates of $0.28 \mathrm{~m} / \mathrm{ky}$ (Gunderson et al., 2014), the $7^{\circ}$ angular difference between the last pelitic strata and the calcarenite hori zon allows estimating a hiatus of about $140 \mathrm{ky}$ in the sedimentary record.

\subsection{The Enza River Methane Derived Authigenic Carbonates}

\subsubsection{Field observations}

Slabs and chimneys occur between $30 \mathrm{~m}$ and $64 \mathrm{~m}$ in the section (Fig. 4). Their appearance corresponds to the initial occurrence of sandy horizons and their frequency increases toward the top of the section, where they are abruptly interrupted by the angular unconformity. The slabs are interlayered in the succession and their thickness varies from a few centimetres in the lower part to various decimetres near the top (Figs. 4 and 6a,b). The slabs are generally discontinuous, even if they show progressively more lateral continuity moving upsection, where the sand content increases. They are highly cemented and massive, without evidence on internal structures. The contact between the slabs and the not cemented hosting sediments is always sharp and well identifiable. Channel like tracks, ca. $1 \mathrm{~cm}$ wide and probably representing invertebrate bioturbation are clearly visible on the external surfaces of the slabs in the upper portion of the section (Fig. 6c).
The chimneys are hosted within the pelitic sediments and crosscut or originate from the slabs. At present, most of the chimneys are in situ and have a sub vertical orientation (Fig. 7), although a few are roughly perpendicular to the stratification (Fig. 6a). The chimneys are generally cylindrical or pipe like in shape (Fig. 7a,b), even if conical and bulbous morphologies also occur (Fig. 7c). Their diameters range from $5 \mathrm{~cm}$ to $35 \mathrm{~cm}$ and their observable lengths are comprised between a few decimetres and $2.5 \mathrm{~m}$. An open conduit can be observed along the centre of the cylindrical concretions (Fig. 7a). However, there are numerous examples where it is completely closed either by carbonate cements or semiconsolidated pelitic sediments (Fig. 7b). The bulbous features show irregular conduits, which have smaller diameters than the pipe like chimneys. The internal structure of chimneys is homo geneous, with the texture composed of fine grained siliciclastics dispersed in the carbonate cement.

\subsubsection{Mineralogy and stable isotopes}

The detailed mineralogical and geochemical characterization of the carbonate samples form the Enza MDAC field is discussed in Viola et al. (in this volume) and is beyond the purposes of this paper. However, a brief summary of these data is presented here due to their importance for the spatial and temporal reconstruction of the Enza MDAC field evolution.

In the Enza outcrop, the carbonate mineralogy does not significantly vary among the different sampled concretions. The carbonate chimneys are mainly composed of authigenic dolomite (>60\% bulk weight) with low and variable amounts of calcite (up to $13 \%)$. Dolomite content is higher into the internal parts of the chimneys, whereas in the external portions increase the calcite cement and the detrital fraction. The detrital fraction (up to $41 \%$ ) is similar in all the samples: major components are quartz, feldspars, plagioclase, clay minerals and micas. The mineralogy of the detrital fraction reflects the characteristics of the hosting pelitic sediments (Viola et al., in this volume). The slabs are composed of authigenic dolomite (up to $80 \% \mathrm{wt}$ ). Calcite is present only in a small area of the $\mathrm{Cr} 2 \mathrm{slab}(4 \% \mathrm{wt})$, collected close to the calcarenite horizon. The dark grey concretions enclosed in the calcarenite horizon ( $\mathrm{Cr} 1$ and $\mathrm{Cr} 3)$ are mainly composed of dolomite, with calcite ( $11 \% \mathrm{wt}$ ) concentrated in a sector of the Cr3B sample (Viola et al., in this volume). Sulphur is strongly enriched $(32,000 \mathrm{ppm})$ in the dark grey concretions and is associated with high contents of pyrite and arsenopyrite ( $5 \% \mathrm{wt})$. 

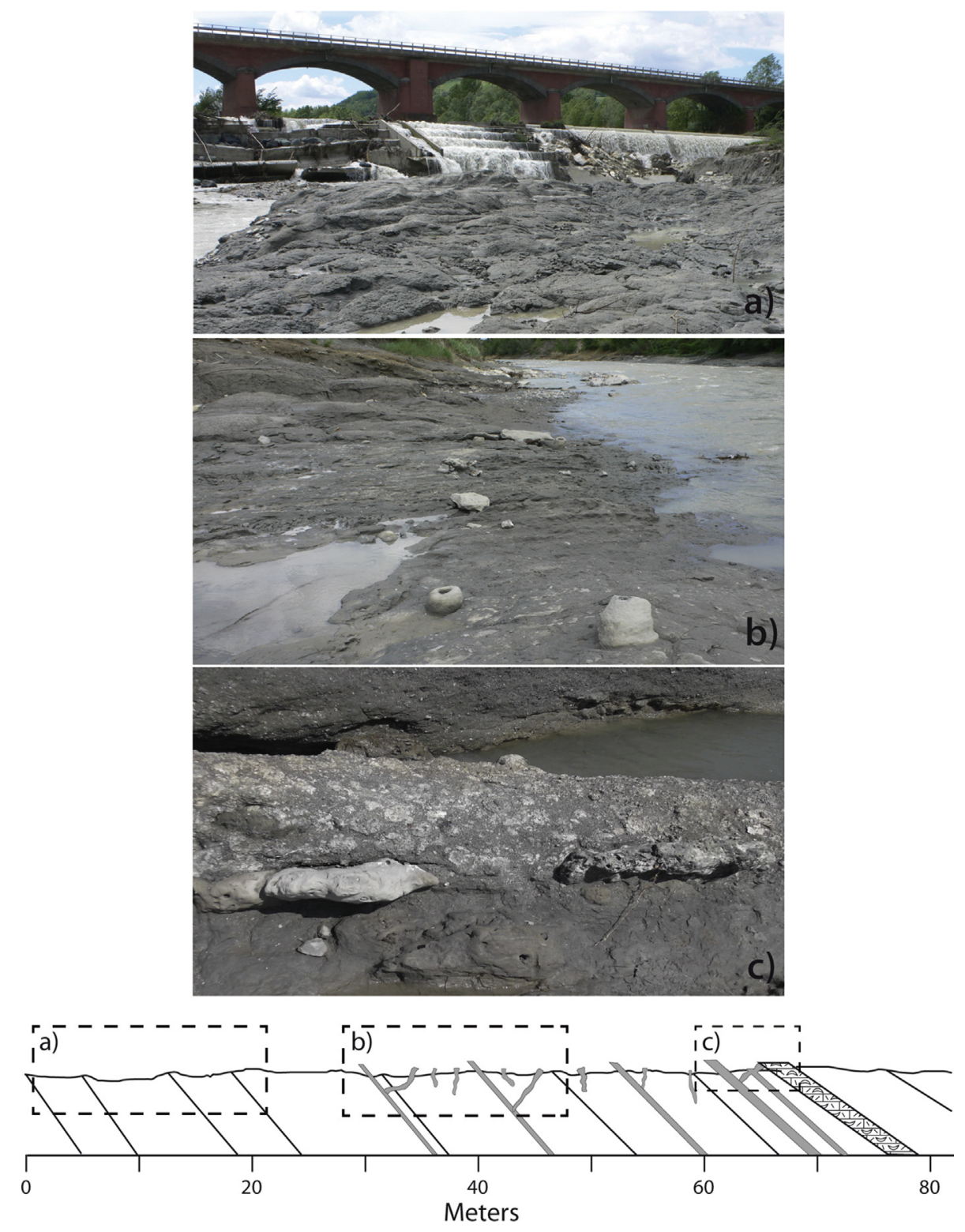

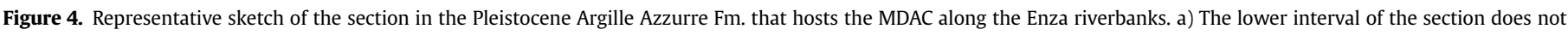

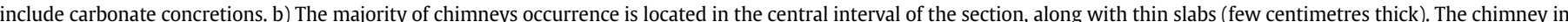

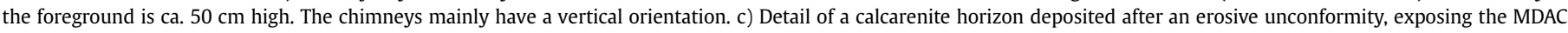
concretions on the seabed. Note the corallinaceous algae encrusting the slabs (ca. $20 \mathrm{~cm}$ thick).

In the Enza MDAC chimneys and slabs the $\delta^{13} \mathrm{C}$ ranges between $8.6 \%$ and $28.56 \%$ VPDB (Fig. 8). More negative values (from 35\%o to $40 \%$ VPDB) have been found in the $\mathrm{Cr} 1$ and $\mathrm{Cr} 3$ concretions enclosed in the calcarenite horizon at the top of the studied section.

The $\delta^{18} \mathrm{O}$ is generally relatively heavy, up to $+6.24 \%$ VPDB. Methane gas is presently seeping in the MDAC field, together with a minor fraction of $\mathrm{C} 2+$ hydrocarbons, and has been sampled and analysed. The determined $\delta^{13} \mathrm{C}$ of $\mathrm{CH}_{4}$ shows a ${ }^{13} \mathrm{C}$ depleted value ( 72\% VPDB).

\section{Discussion}

\subsection{Origin of methane gas in the Enza MDAC field}

The extensive carbonate precipitation in the Enza MDAC field required a constant leakage of methane over several thousands of years. The assessment of methane origin is fundamental to reconstruct the hydrocarbon migration in the area and the MDAC for mation. In the Northern Apennines foothills close to the Enza River section, the present day cold seeps activity and mud volcano edifices are correlated to the regional petroleum system (Oppo et al., 2013). This is characterized by a mature source rock, which is located deeper than the deformed Miocene foredeep sediments forming the hydrocarbon reservoirs (Oppo et al., 2013). The progressive migration of oil and thermogenic gas in the Miocene successions led to their accumulation in the ramp anticlines. The hydrocarbon migration mechanism towards the surface is mainly provided by normal faults disrupting the sealing units (Fig. 2)(Oppo et al., 2013). However, this migration system could not be considered as responsible for the formation of the Enza River MDAC field. The fluid migration from the Miocene reservoir and the Quattro Castella anticline can be ruled out due to the absence of 


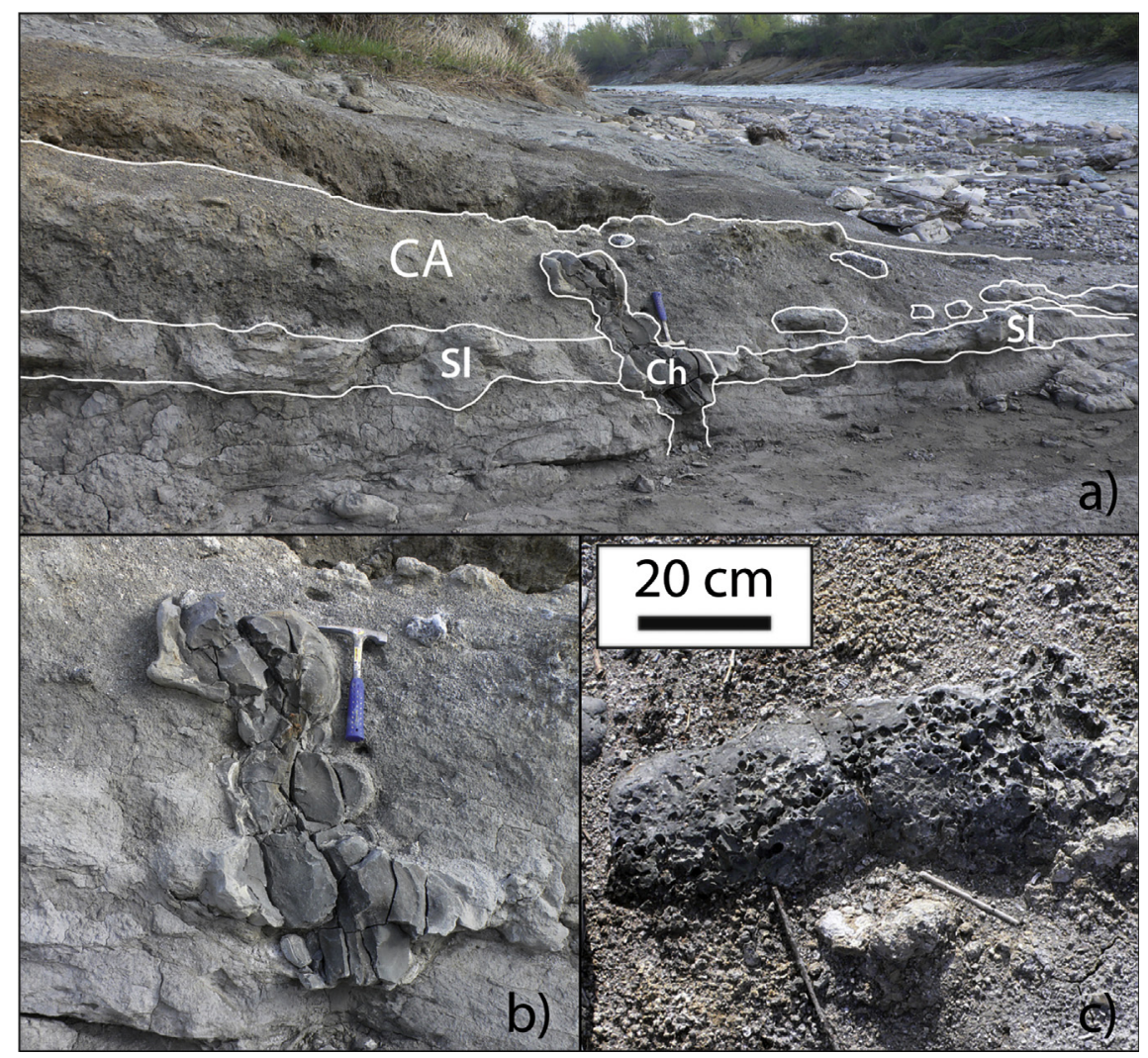

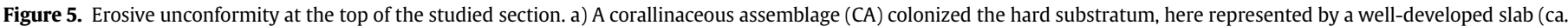

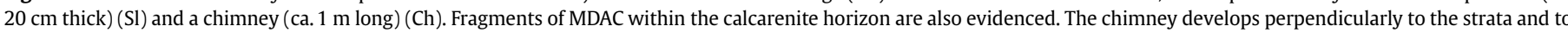

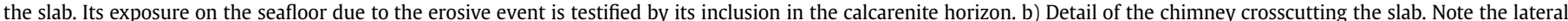

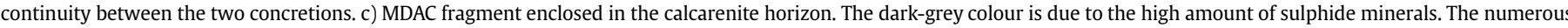
holes on the surface are due to boring organisms. (For interpretation of the references to colour in this figure legend, the reader is referred to the web version of this article.)

suitable pathways, such as normal faults or up dip carrier beds, connecting this structure with the Pleistocene succession hosting the MDAC field (Fig. 3).

The Messinian and Pliocene foredeep successions are often the source rocks of large volumes of biogenic gas, now exploited in more central and eastern areas of the Po Plain. They are composed of turbiditic successions, including a Piacenzian age sapropel bearing interval about $60 \mathrm{~m}$ thick (Capozzi and Picotti, 2003, 2010). Mean Total Organic Carbon (TOC) contents of $0.4 \%$ and $1.0 \%$ occur in the turbiditic and sapropel sequences, respectively (Capozzi et al., 2006). Such low TOC are due to the dilution of the organic matter in the thick successions, therefore high generation potential is still provided. The analysed methane gas presently seeping in the MDAC field has $72 \% 0 \delta^{13} \mathrm{C}$ (VPDB), which is indic ative of its biogenic origin. This gas matches the stable isotopic signature of the biogenic methane generated by the described Pliocene successions that occur in the Romagna Apennines and Adriatic Sea (Mattavelli et al., 1983; Capozzi and Picotti, 2010). Therefore, the leakage of biogenic methane should be considered as responsible for the formation of the MDAC field. The absence of suitable pathways that could have conveyed thermogenic gas from the Miocene reservoirs and the origin of the methane presently seeping along the Enza River are sustaining this interpretation.

The syndepositional strata growth in the forelimb of the Quattro Castella Anticline provided the up dip carrier beds for the migration, toward the Enza MDAC field, of hydrocarbons and connate saline waters from the Pliocene strata located to the North (Fig. 3). The activity of Quattro Castella and Ghiardo anticlines is responsible for the progressive deformation and uplift of the Plio-
Pleistocene sediments, now outcropping along the Enza river banks (Boccaletti et al., 2010; Ponza et al., 2010).

\subsection{Origin of the Enza MDAC concretions}

The geochemical processes regulating the precipitation of methane derived carbonates are governed by the establishment in the sedimentary succession of bacterially mediated Anaerobic Oxidation of Methane Sulphate Reducing (AOM SR) conditions, according with the net reaction (Reeburgh, 1980):

$\mathrm{CH}_{4}+\mathrm{SO}_{4}^{2-} \rightarrow \mathrm{HCO}_{3}^{-}+\mathrm{HS}^{-}+\mathrm{H}_{2} \mathrm{O}$

The AOM therefore increases the bicarbonate in the system and produces the concentrations of dissolved inorganic carbonate species necessary to the MDAC precipitation. The mineralogy of carbonate cements that precipitate as a consequence of AOM SR is influenced by the geochemistry of the environment where they form. Despite the exact pathway by which dolomite precipitates in sediments affected by AOM is still under debate, we can consider the general reaction (Moore et al., 2004):

$$
\mathrm{Ca}^{2+}+\mathrm{Mg}^{2+}+2 \mathrm{CO}_{3}^{2-} \leftrightarrow \operatorname{CaMg}\left(\mathrm{CO}_{3}\right)_{2}
$$

This condition is encountered when AOM reaches its maximum at the Sulphate-Methane Transition Zone (SMTZ), which is a thin horizon (ca. $20-30 \mathrm{~cm}$ thick) where the $\mathrm{SO}_{4}$ is almost totally removed and the $\mathrm{HCO}_{3}$ reaches its maximum concentration (e.g. Rodriguez et al., 2000; Ussler and Paull, 2008; Paull and Ussler, 


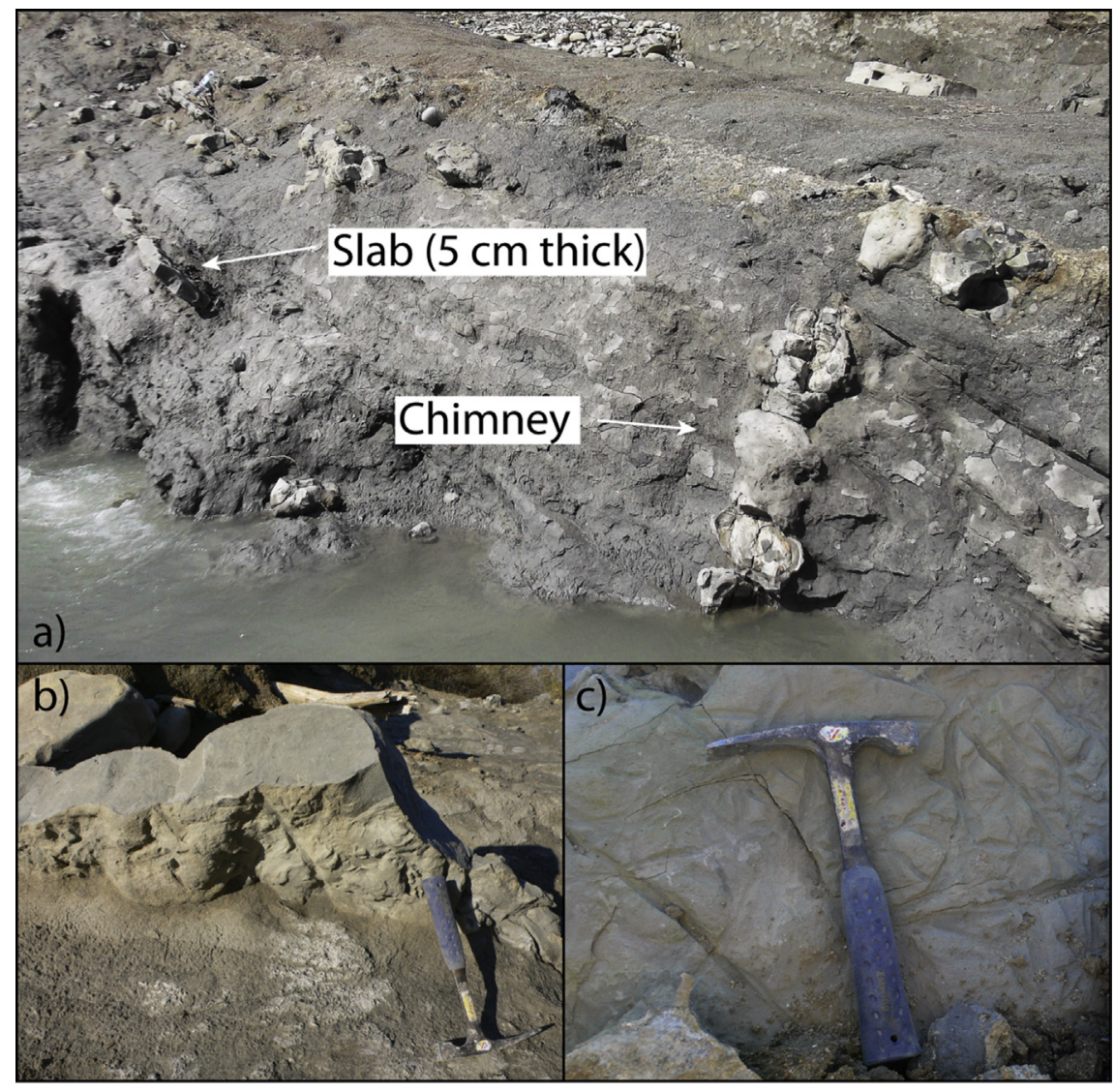

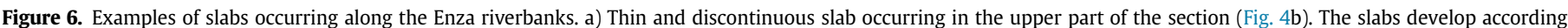

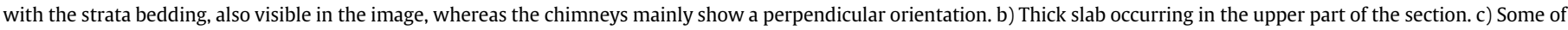
the thicker slabs present channel-like track on the surfaces, probably representing former bioturbation.

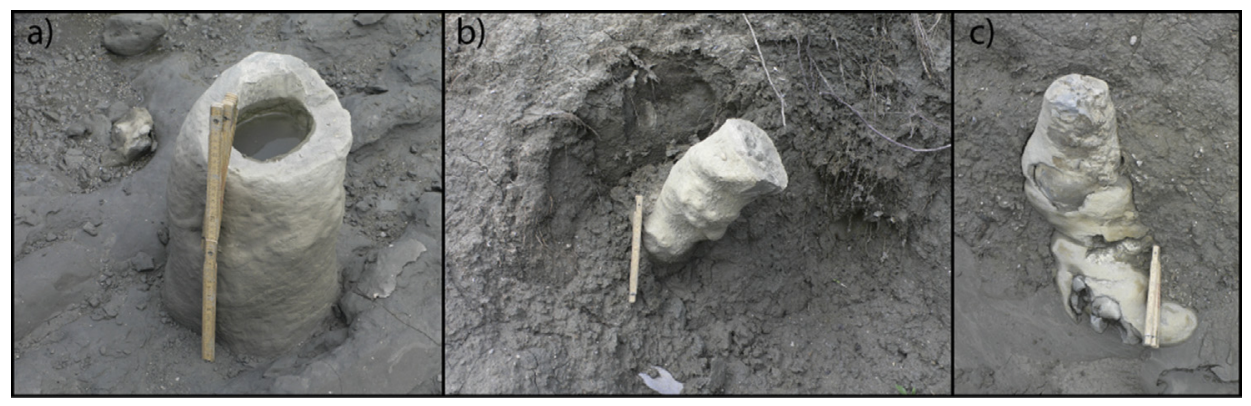

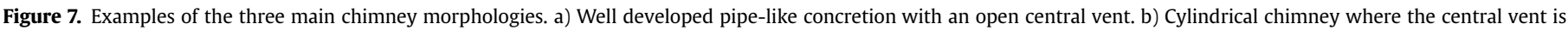
absent due to the complete cementation of the inner portions. c) Conical chimney with a cemented central vent.

2008). The magnesium can form complexes with the $\mathrm{SO}_{4}$; then, concentrations of sulphate even less than $5 \%$ in the pore water could inhibit the dolomite precipitation (Douglas, 2005; Magalhaes et al., 2012). Therefore, the chimneys and slabs in the Enza MDAC field, which are almost entirely composed of dolomite, formed in sulphate depleted waters and in absence of marine water supply from the sediment-water interface.

The authigenic carbonates formation exploits the dissolved inorganic carbon (DIC) present in the pore water, without a significant isotopic fractionation (Diaz del Rio et al., 2003; Paull and Ussler, 2008). Therefore, the MDAC could preserve the $\delta^{13} \mathrm{C}$ values representative of the DIC sources, which include decomposing organic matter, marine shells, thermogenic and biogenic methane and residual $\mathrm{CO}_{2}$ from methanogenesis (e.g. Nyman et al., 2010) and also of their mixing. In the Enza River chimneys the $\delta^{13} \mathrm{C}$ varies randomly along the section and ranges from about $8.6 \%$ oto $28.56 \%$ VPDB. These values are often found in similar con cretions and are indicative of origin from AOM processes (e.g. Rodriguez et al., 2000; Diaz del Rio et al., 2003; Capozzi et al., 2012). Despite the range of $\delta^{13} \mathrm{C}$ values measured in the Enza MDAC is commonly interpreted as fingerprint of thermogenic methane, it has been demonstrated that this is not always true if the geological and petroleum histories of the area are considered (Capozzi et al., 2012). In the Enza MDAC the ${ }^{13} \mathrm{C}$ enriched cements, with respect to the original biogenic methane, indicate that this methane is not the only carbon source. Therefore, other DIC sources could have 


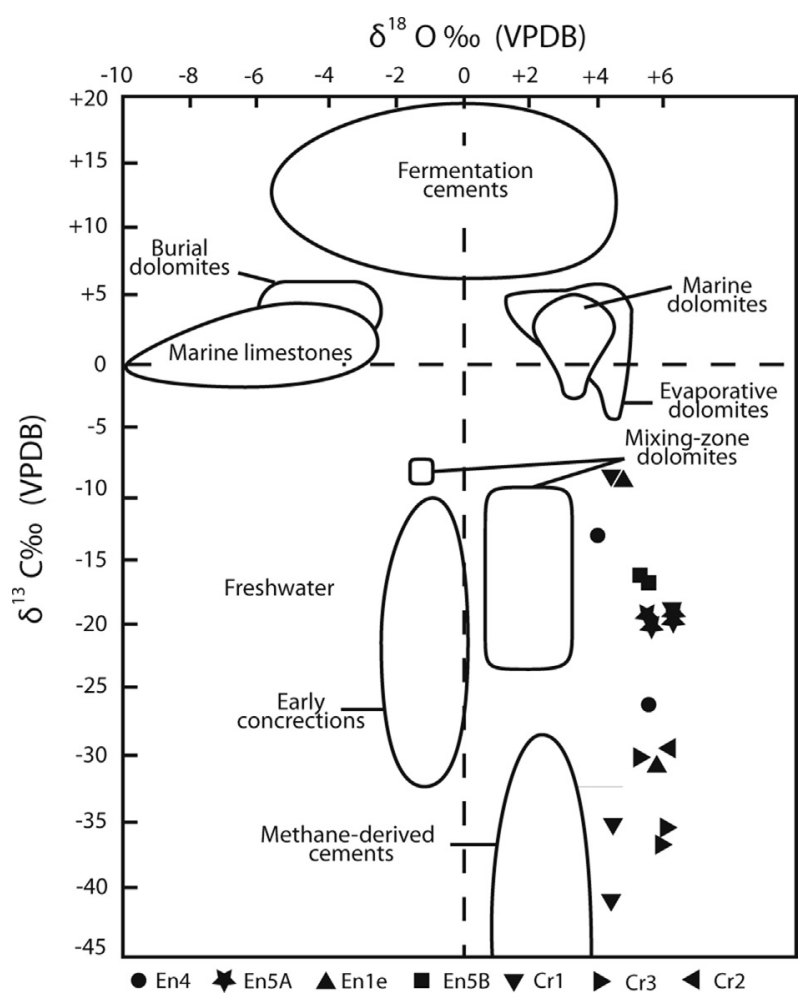

Figure 8. Carbon and oxygen stable isotopes diagram, modified after Nelson and Smith (1996), based on generalized isotopic fields for a selection of different carbonates typologies from New Zealand. The isotopic values of carbonates analysed in this study are plotted. The plot evidences the origin of the $\delta^{13} \mathrm{C}$ in the carbonate cements from both AOM-SR and the mixing with different sources of DIC.

contributed to the precipitation of the carbonate concretions, such as the DIC in the connate waters migrating together with the hydrocarbons.

Reducing condition, occurrence of pyrite and arsenopyrite and more negative $\delta^{13} \mathrm{C}$ values have been found in the dark grey concretions sampled within the calcarenite horizon at the top of the studied section. In these concretions a slight increase of calcite cements has been also documented. These evidences suggest that further circulation of fairly different fluids, where marine sulphate can be used for AOM, occurred through this sedimentary horizon deposited after a 140 ky stratigraphic hiatus.

Despite previous works identified the dissociation of gas hydrates as the source of heavy $\delta^{18} \mathrm{O}$ in worldwide MDAC fields (e.g. Aloisi et al., 2000; Pierre and Rouchy, 2004; Dela Pierre et al., 2010), this process cannot be taken into account for the Enza River concretions. The whole thickness of the Argille Azzurre succession hosting the MDAC has been unable to reach the gas hydrates stability zone, even during glacial periods, as it was deposited in a shallow continental shelf at ca. 80 mwater depth and far from polar latitudes. The studied succession encompasses the Early Pleistocene climatic intervals that show average values of $\delta^{18} \mathrm{O}$ in the marine water of about $+3 \%$ VPDB (Zachos et al., 2001). Moreover, the dolomite phase in the carbonates usually shows an increase of the oxygen heavy isotope of $+2-4 \%$ owith respect to the initial water values (Budd, 1997). Considering the initial value of water and the enrichment due to the dolomite pre cipitation, the total +4 to $+6 \% \delta^{18} \mathrm{O}$ in the Enza MDAC concretions could be easily explained.

\subsection{Model of chimneys formation}

Between $30 \mathrm{~m}$ and $45 \mathrm{~m}$ in the section, the mostly pelitic sediments host narrow pipe like conduits. Only a few discontinuous and thin (about $5 \mathrm{~cm}$ thick) slabs occur in this interval where the silt and very fine sand content increases.

The methane migration through fine sand or coarser sediments rarely leads to the formation of carbonate chimney structures. As a consequence of the high sediment permeability the fluids could easily diffuse radially from a main migration pathway. This scenario does not require the formation of an open central vent (Choi et al., 2011) and, when a chimney like concretion forms, it usually results completely cemented. The central portion of the chimney is the first to cement and acts as a nucleation point for the carbonate precipitation (Magalhaes, 2007). The fluids continue to use the same migration pathway below the zone already cemented, but when they reach this latter they will flow along its external area and progressively enlarge the concretion. This "inside to outside" precipitation model does not limit the final size of the chimneys, which is controlled exclusively by the methane concentrations and by the AOM SR process.

The gas migration in pelitic sediments can occur by means of pre existing discontinuities, such as fractures and burrows in the shallow subsurface (Paull and Ussler, 2008), or by conduit opening and fracturing by the pressurized fluids, which laterally displace the particles along zones with lower grain packing density (Choi et al., 2011). The latter mechanism of forced intrusion of the fluids in the pelitic sediments seems the most suitable process to explain the formation of pipe like concretions. The majority of Enza MDAC chimneys occur in pelitic sediments and are often charac terized by an open central conduit generated by the gas migration. Two models of chimneys growth have been proposed in the literature:

- Magalhaes (2007) identifies a methane rich zone around a central open conduit. The carbonates precipitation proceeds radially from this latter towards the external sectors, according with the capability of the AOM SR reaction front to move away from the conduit into the sulphate rich zone. Once the inner portions are completely cemented, the methane is not able to reach the outer areas and the precipitation stops.

- Nyman et al. (2010) propose a different model of chimneys formation. The migrating methane initially permeates a cylindrical area of sediment. The beginning of carbonate precipitation occurs along the edges of this area, thus delimiting the maximum diameter of the forming chimney, and progressively proceeds inwards as a result of AOM SR acting in the inner zones. This process generates a central vent due to the increased force of the fluids flow passing through a confined system. Both the models account that, if the conduit is filled with sediments and sulphate rich pore water, different methane migration episodes can lead to the cementation of the inner portion of the chimney and to the formation of concentric growth layers up to the complete closure of the central vent. Gradual younger cements should therefore be documented moving inwards in the concretion.

The Enza chimneys mineralogy shows that the bulk of the cements are formed by dolomite, with low amounts of calcite occurring only in the more external portion (Viola et al., in this volume). Therefore, the formation of the Enza chimneys can be related with the second proposed model. In fact, the methane diffuses in the sediments radially from a central conduit and the carbonate precipitates first in the external areas, as testified by the increased calcite content due to the proximity with the $\mathrm{SO}_{4}$ of marine water. This partially cemented layer acts as barrier that limits the fluid exchange between internal and external portions of the methane permeated zone and, therefore, progressively leads to the total sulphates removal from the solution in the inner areas. The absence of calcite in the internal portions of the Enza chimneys 
rules out that sulphate rich seawater migrated in the central vent from above. This mechanism of formation does not require a widespread $\mathrm{SO}_{4}$ deficiency in the area of chimneys precipitation. In fact, during the first stages of formation, the Enza chimneys could have been focused SMTZ into a sedimentary succession containing sulphate rich pore water, with the main SMTZ occurring in the deeper succession (Fig. 9). Only after the progressive burial and the upward migration of the SMTZ they could have entered into a fully $\mathrm{SO}_{4}$ free/methane rich environment, which allowed the precipitation of the bulk of the dolomite cements. Moreover, the connate water associated with the hydrocarbons in this area is depleted in $\mathrm{SO}_{4}$ and enriched in $\mathrm{HCO}_{3}$ (e.g. Oppo et al., 2013), thus could provide an additional DIC source.

\subsection{Model of slabs formation}

In the upper section, between $45 \mathrm{~m}$ and $64 \mathrm{~m}$, the increased number of MDAC concretions is related with the higher frequency of fine sand strata in the sediments. The gas migration in water saturated sandy sediments is controlled by capillary invasion, which causes the progressive pore water displacement and methane infiltration in the relatively large pore spaces (Choi et al., 2011). This allows a widespread fluid diffusion and, possibly, an increased gas flux and AOM rates. This aspect appears to be confirmed by the occurrence of thicker and more laterally continuous slabs, often crosscut by chimneys, which cement the horizons with coarser granulometry. This suggests that the slabs acted as the main methane migration pathways from depth.

The depth of the SMTZ in the sedimentary column could vary between a few $\mathrm{cm}$ and tens of meters below the seafloor, being directly related to the amount of $\mathrm{SO}_{4}$ diffusing downward in the phreatic aquifer and to the methane flux from depth (Moore et al., 2004). High methane flux generates high AOM rates (Luff and Wallmann, 2003; Moore et al., 2004), which in turn shifts the SMTZ towards shallower horizons. Moreover, the rate of dolomite precipitation is relatively constant regardless the depth (Moore

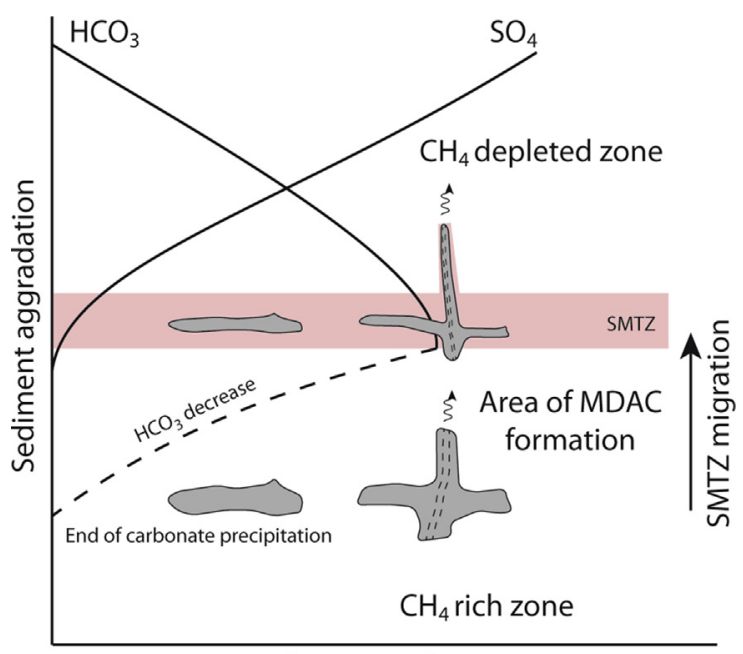

Concentration

Figure 9. Vertical profiles of $\mathrm{SO}_{4}$ and $\mathrm{HCO}_{3}$ in the subsurface sediments. The SMTZ marks the almost complete removal of sulphates from the pore water and the maximum enrichment of $\mathrm{HCO}_{3}$. In the interval below the transition zone the fluids are rich in methane. The chimneys can act as focused SMTZ in the sulphate-rich sediments. The MDAC precipitation begins at the SMTZ and continues within the methane-rich zone after the SMTZ moved upward due to sediment aggradation. The carbonates precipitation proceeds, possibly fed by a second DIC source in the connate water migrating together with the methane. et al., 2004), indicating that the diffusive fluxes of $\mathrm{Mg}$ and $\mathrm{Ca}$ from seawater are not limiting factors.

The time required by the AOM SR process to produce the $\mathrm{HCO}_{3}$ and $\mathrm{SO}_{4}$ concentration profiles lays on the scale of centuries (Ussler and Paull, 2008) (Fig. 9), as generally observed in the subsurface of marine fine grained depositional systems. Therefore, when a constant gas flux is present, the SMTZ tends to move upwards according with the sedimentation rate, which is normally in the range of few decimetres per thousand years (Paull and Ussler, 2008; Rodriguez et al., 2000).

Numerical modelling showed that the rate of carbonate precipitation due to AOM SR could produce a $1 \mathrm{~m}$ thick calcite layer over a period of ca. 20,000 years (Luff and Wallmann, 2003). Taking into account this model, if the slabs outcropping along the Enza section were formed only by calcite, they would be cemented during an interval of thousand years, varying with their different thicknesses. It is recognized that the dolomite precipitation is influenced by several factors, including the kinematic velocity of carbonates dissolution/precipitation and the bacterial activity mediation. Therefore, the studied dolomite concretions could have been formed during periods longer than indicated for calcite (e.g. Misra, 2012). In the Enza section interested by the slabs occurrence, the sedimentation rate is about $0.28 \mathrm{~m} / \mathrm{ky}$ (Gunderson et al., 2014), while the MDAC precipitation rates are slower than $0.05 \mathrm{~m} / \mathrm{ky}$ (Luff and Wallmann, 2003). This suggests that the formation of the concretions initiated in the SMTZ and continued after this moved upwards in more recently deposited sediments (Fig. 9). Therefore, the interval characterized by sulphate free and $\mathrm{HCO}_{3}$ rich pore waters has to persist below the SMTZ, where the MDAC dolomite precipitation continues to occur as long as the carbonate ions are available. This process could be further supported by the $\mathrm{HCO}_{3}$ rich and $\mathrm{SO}_{4}$ totally depleted waters migrating together with the methane from the reservoir.

\section{Conclusions}

The Enza MDAC field is a quite unique example where the MDAC precipitation can be correlated to a high resolution stratigraphic reconstruction and to the formation of the plumbing system. The MDAC concretions exposed along the Pleistocene age Enza River section formed as a consequence of the leakage of biogenic methane generated by a Pliocene source rock buried in the Po plain nearby the Northern Apennines foothills. The fluid leakage has been active for several thousand years when the basinal conditions allowed the sediment deposition in a continental shelf environment. A major erosive phase, marked by an angular unconformity, exposed the buried concretions. The stratigraphic hiatus involves up to $140 \mathrm{ky}$, however the thickness of eroded/not deposited sediments could not be calculated. The change in depositional setting led to gas leakage on the seabed, as could be inferred by the high amount of pyrite occurring in the calcarenite horizon. The methane migration in the Enza sediments varies according with their granulometry, leading to the forma tion of chimneys mainly in the pelitic sediments and of slabs where the sand fraction increases.

The sedimentation rate in the Enza Pleistocene sediments is two orders of magnitude higher than the MDAC precipitation rate. Therefore, the SMTZ migrated upwards faster than the time required for the formation of the observed carbonates. Because the precipitation of authigenic dolomite cements took place during thousands years and in absence of subsurface exchanges with $\mathrm{SO}_{4}$ rich water, could be hypothesized that the connate water migrating with the methane acted as second DIC source during the MDAC formation in the $\mathrm{CH}_{4}$ rich zone. This contribution could be responsible for the variability of $\delta^{13} \mathrm{C}$ in the carbonates. 


\section{Acknowledgments}

Funding was provided by the Italian PRIN 2009 Project (MIUR research grants to $\mathrm{R}$. Capozzi). The authors wish to thank Prof. Joachim Reitner (Department of Geobiology, Centre for Geosciences, Georg August University of Gottingen, Germany) for contributing in the stable isotopes analyses on MDAC cements. We thank Dr. Quiliang Sun and an anonymous reviewer for the useful comments on the article manuscript.

\section{References}

Aloisi, G., Pierre, C., Rouchy, J., Foucher, J., Woodside, J., 2000. Methane-related authigenic carbonates of eastern Mediterranean Sea mud volcanoes and their possible relation to gas hydrate destabilisation. Earth Planet. Sci. Lett. 184 321338.

Aslan, A., Warne, A., White, W., Guevara, E., Smyth, R., Raney, J., Gibeaut, J., 2001. Mud volcanoes of the Orinoco Delta, eastern Venezuela. Geomorphology 41, 323336.

Balestrieri, M.L., Bernet, M., Brandon, M.T., Picotti, V., Reiners, P., Zattin, M., 2003. Pliocene and Pleistocene exhumation and uplift of two key areas of the northern Apennines. In: Bartolini, C., Piccini, L., Catto, N.R. (Eds.), Uplift and Erosion Driving Processes and Resulting Landforms; Dynamic Relations Be-tween Crustal and Surficial Processes, Quaternary International, vol. 101 102, pp. 6773.

Bartolini, C., 2003. When did the Northern Apennine become a mountain chain? In: Bartolini, C., Piccini, L., Catto, N.R. (Eds.), Uplift and Erosion; Driving Processes and Resulting Landforms; Dynamic Relations Between Crustal and Surficial Processes, Quaternary International, vol. 101 102, pp. 7580.

Boccaletti, M., Corti, G., Martelli, L., 2010. Recent and active tectonics of the external zone of the Northern Apennines (Italy). Int. J. Earth Sci. 100, 13311348.

Boetius, A., Ravenschlag, K., Schubert, C., Rickert, D., 2000. A marine microbial consortium apparently mediating anaerobic oxidation of methane. Nature 407, 623626

Bonini, M., 2007. Interrelations of mud volcanism, fluid venting, and thrustanticline folding: examples from the external northern Apennines (Emilia-Romagna, Italy). J. Geophys. Res. 112, B08413.

Budd, D.A., 1997. Cenozoic dolomites of carbonate islands: their attributes and origin. Earth Sci. Rev. 42, 147.

Capozzi, R., Picotti, V., 2003. Pliocene sequence stratigraphy, climatic trends and sapropel formation in the Northern Apennines (Italy). Palaeogeogr. Palaeoclimatol. Palaeoecol. 190, 349371.

Capozzi, R., Picotti, V., 2010. Spontaneous Fluid Emissions in the Northern Apennines: Geochemistry, Structures and Implications for the Petroleum System. In: Geological Society London Special Publications, vol. 348, pp. 115135.

Capozzi, R., Dinelli, E., Negri, A., Picotti, V., 2006. Productivity-generated annual laminae in mid-Pliocene sapropels deposited during precessionally forced periods of warmer Mediterranean climate. Palaeogeogr. Palaeoclimatol. Palae-oecol. 235, 208222.

Capozzi, R., Guido, F.L., Oppo, D., Gabbianelli, G., 2012. Methane-Derived Authigenic Carbonates (MDAC) in northern-central Adriatic Sea: relationships between reservoir and methane seepages. Mar. Geol. 332 334, 174188.

Choi, J.-H., Seol, Y., Boswell, R., Juanes, R., 2011. X-ray computed-tomography

im- aging of gas migration in water-saturated sediments: from capillary invasion to conduit opening. Geophys. Res. Lett. 38, LI7310.

Clari, P., Cavagna, S., Martire, L., Hinziker, J., 2004. A Miocene mud volcano and its plumbing system: a chaotic complex revisited (Monferrato, NW Italy). J. Sediment. Res. 74, 662676 .

Conti, S., Fontana, D., Gubertini, A., Sighinolfi, G., Tateo, F., Fioroni, C., Fregni, P., 2004. A multidisciplinary study of middle Miocene seep-carbonates from

Northern Apennines foredeep (Italy). Sediment. Geol. 169, 119.

Cremaschi, M., Papani, G., 1975. Contributo preliminare alla neotettonica del margine padano dell'appennino: le forme terrazzate comprese tra Cavriago Quattro Castella (Reggio E. Acta Nat. Ateneo Parmense 11, 335371 (in Italian).

Dela Pierre, F., Martire, L., Natalicchio, M., Clari, P., Petrea, C., 2010. Authigenic carbonates in Upper Miocene sediments of the Tertiary Piedmont Basin (NW Italy): vestiges of an ancient gas hydrate stability zone? Geol. Soc. Am. Bull. 122, 9941010.

Diaz-del-Rio, V., Somoza, L., Martinez-Frias, J., Mata, M., Delgado, A., HernandezMolina, F., Lunar, R., Martin-Rubi, J., Maestro, A., Fernandez-Puga, M., 2003. Vast fields of hydrocarbon-derived carbonate chimneys related to the accretionary wedge/olistostrome of the Gulf of Cadiz. Mar. Geol. 195, 177200.

Dimitrov, L.I., 2002. Mud volcanoes - the most important pathway for degassing deeply buried sediments. Earth Sci. Rev. 59, 4976.

Douglas, S., 2005. Mineralogical footprints of microbial life. American Journal of Science 305, 503525.

Ghielmi, M., Minervini, M., Nini, C., Rogledi, S., Rossi, M., Vignolo, A., 2010. Sedimentary and Tectonic Evolution in the Eastern Po-Plain and Northern Adriatic Sea Area from Messinian to Middle Pleistocene (Italy), vol. 21. Rendiconti Lincei, pp. S131 S166.
Goldsmith, J.R., Graf, D.L., 1958. Relation between lattice constants and composition of the $\mathrm{Ca} \mathrm{Mg}$ carbonates. Am. Mineral. 43, 84101.

Gunderson, K.L., Pazzaglia, F.J., Picotti, V., Anastasio, D.A., Kodama, K.P., Rittenour, T. Frankel, K.F., Ponza, A., Berti, C., Negri, A., Sabbatini, A., 2014. Unraveling tec tonic and climatic controls on synorogenic growth strata (Northern Apennines, Italy). Geol. Soc. Am. Bull. 126, 532552.

Heller, C., Blumenberg, M., Hoppert, M., Taviani, M., Reitner, J., 2012. Terrestrial mud volcanoes of the Salse di Nirano (Italy) as a window into deeply buried organic-rich shales of Plio-Pleistocene age. Sediment. Geol. 263264 , 202209.

Hovland, M., Svensen, H., Forsberg, C.F., Johansen, H., Fichler, C., Fosså, J.H., Jonsson, R., Rueslåtten, H., 2005. Complex pockmarks with carbonate ridges off mid-Norway: product of sediment degassing. Mar. Geol. 218, 191206.

Kvenvolden, K.A., Rogers, B.W., 2005. Gaia's breath global methane exhalations. Marine and Petroleum Geology 22, 579590.

Luff, R., Wallmann, K., 2003. Fluid flow, methane fluxes, carbonate precipitation and biogeochemical turnover in gas hydrate-bearing sediments at Hydrate Ridge, Cascadia Margin: numerical modeling and mass balances. Geochim. Cosmochim. Acta 67, 34033421.

Lumsden, D.N., 1979. Discrepancy between thin-section and X-ray estimates of dolomite in limestone. J. Sediment. Petrol. 49, 429435.

Magalhaes, V.H., 2007. Authigenic Carbonates and Fluid Escape Structures in the Gulf of Cadiz (Ph.D. thesis). University of Aveiro, p. 422.

Magalhaes, V.H., Pinheiro, L.M., Ivanov, M.K., Kozlova, E., Blinova, V., Kolganova, J. Vasconcelos, C., McKenzie, J.A., Bernasconi, S.M., Kopf, A.J., Díaz-Del-Rio, V., González, F.J., Somoza, L., 2012. Formation processes of methane-derived authigenic carbonates from the Gulf of Cadiz. Sediment. Geol. 243244 155168.

Mattavelli, L., Ricchiuto, T., Grignani, D., Schoell, M., 1983. Geochemistry and habitat of natural gases in Po basin, Northern Italy. AAPG Bull. 67, 22392254.

Mazzini, A., Duranti, D., Jonk, R., Parnell, J., Cronin, B.T., Hurst, A., Quine, M., 2003. Palaeo-carbonate seep structure above an oil reservoir, Gryphon Field, Tertiary, North Sea. Geo Mar. Lett. 23, 323339

Mazzini, A., Svensen, H., Planke, S., Guliyev, I., Akhmanov, G.G., Fallik, T., Banks, D. 2009. When mud volcanoes sleep: insight from seep geochemistry at the Dashgil mud volcano, Azerbaijan. Mar. Pet. Geol. 26, 17041715.

Michaelis, W., Seifert, R., Nauhaus, K., Treude, T., Thiel, V., Blumenberg, M. Knittel, K., Gieseke, A., Peterknecht, K., Pape, T., Boehm, A., Amann, R., Jørgensen, B.B., Widdel, F., Peckmann, J., Pimenov, N.V., Gulin, M.B., 2002. Microbial reefs in the Black Sea fueled by anaerobic oxidation of methane. Science 297, 10131015.

Misra, K.C., 2012. Introduction to Geochemistry: Principles and Applications. WileyBlackwell, p. 452

Moore, T.S., Murray, R.W., Kurtz, A.C., Schrag, D.P., 2004. Anaerobic methane oxidation and the formation of dolomite. Earth Planet. Sci. Lett. 229,

141154.

Nelson, C.S., Smith, A.M., 1996. Stable oxygen and carbon isotope compositional fields for skeletal and diagenetic components in New Zealand Cenozoic nontropical carbonate sediments and limestones: a synthesis and review. N. Z. J. Geol. Geophys. 39, 93107.

Nyman, S.L., Nelson, C.S., Campbell, K.A., 2010. Miocene tubular concretions in East Coast Basin, New Zealand: analogue for the subsurface plumbing of cold seeps. Mar. Geol. 272, 319336.

Oppo, D., Capozzi, R., Picotti, V., 2013. A new model of the petroleum system in the Northern Apennines, Italy. Mar. Pet. Geol. 48, 5776.

Oppo, D., Capozzi, R., Nigarov, A., Esenov, P., 2014. Mud volcanism and fluid geochemistry in the Cheleken peninsula, western Turkmenistan. Mar. Pet. Geol.

57, 122134.

Paull, C., Ussler III, W., 2008. Re-evaluating the significance of seafloor accumulations of methane-derived carbonates: seepage or erosion indicators?. In: Proceedings of the 6th International Conference on Gas Hydrates (ICGH 2008), Vancouver, British Columbia, Canada, July 610.

Pierre, C., Rouchy, J.-M., 2004. Isotopic compositions of diagenetic dolomites in the Tortonian marls of the western Mediterranean margins: evidence of past gas

hydrate formation and dissociation. Chem. Geol. 205, 469484.

Ponza, A., 2010. Tectonic Geomorphology and Active Strain of the Northern Apennines Mountain Front (Ph.D. thesis). University of Bologna, pp. 1134.

Ponza, A., Pazzaglia, F.J., Picotti, V., 2010. Thrust-fold activity at the mountain front of the Northern Apennines (Italy) from quantitative landscape analysis. Geomorphology 123, 211231.

Reeburgh, W.S., 1980. Anaerobic methane oxidation: rate depth distributions in Skan Bay sediments. Earth Planet. Sci. Lett. 47, 345352.

Reitner, J., Peckmann, J., Blumenberg, M., Michaelis, W., Reimer, A., Thiel, V., 2005. Concretionary methane-seep carbonates and associated microbial communities in Black Sea sediments. Palaeogeogr. Palaeoclimatol. Palaeoecol. 227, 1830 .

Ricci Lucchi, F., 1986. The foreland basin system of the Northern Apennines and related clastics wedges; a preliminary outline. In: Boccaletti, M., Gelati, R., Ricci Lucchi, F. (Eds.), Paleogeography and Geodynamics of the Peri-Tyrrhenian Area, Proceedings, Giornale di Geologia, vol. 48, pp. 165185

Rodriguez, N.M., Paull, C.K., Borowski, W.S., 2000. 30. Zonation of authigenic carbonates within gas hydrate-bearing sedimentary sections on the Blake Ridge: offshore southeastern north America. In: Paull, C.K., Matsumoto, R., Wallace, P.J., Dillon, W.P. (Eds.), Proceedings of the Ocean Drilling Program, Scientific Results, vol. 164, pp. 301312. 
Scardia, G., De Franco, R., Muttoni, G., Rogledi, S., Caielli, G., Carcano, C., Sciunnach, D., Picciin, A., 2012. Stratigraphic evidence of a Middle Pleistocene climate-driven flexural uplift in the Alps. Tectonics 31, TC6004.

Sun, Qiliang, Wu, Shiguo, Cartwright, Joe, Hesheng, Shi, 2012. Shallow gas and it origin in the Pearl River Mouth Basin, northern South China Sea. Mar. Geol. $315318,114$.

Ussler III, W., Paull, C.K., 2008. Rates of anaerobic oxidation of methane and authigenic carbonate mineralization in methane-rich deep-sea sediments inferred from models and geochemical profiles. Earth Planet. Sci. Lett. 266, 271 287.
Viola, I., Oppo, D., Franchi, F., Capozzi, R., Dinelli, E., Liverani, B., Taviani, M., 2015 Mineralogy, geochemistry and petrography of methane-derived authigenic carbonates from Enza River, Northern Apennines (Italy). Mar. Pet. Geol. ISSN: 0264-8172 http://dx.doi.org/10.1016/j.marpetgeo.2015.03.011. Available online 20 March 2015 (in this volume).

Zachos, J., Pagani, M., Sloan, L., Thomas, E., Billups, K., 2001. Trends, rhythms, and aberrations in global climate 65 Ma to present. Science 292, 686693.

Zattin, M., Picotti, V., Zuffa, G.G., 2002. Fission-track reconstruction of the front of the Northern Apennine thrust wedge and overlying Ligurian unit. Am. J. Sci. 302,346379 